\title{
ACCUMULATION OF B CHROMOSOMES IN THE GERM LINE OF LOCUSTA MIGRATORIA*
}

\author{
HIROSHI KAYANO \\ Department of Biology, Kyushu University, Fukuoka, Japan
}

Received 1.ix.70

\section{INTRODUGTION}

Several Acrididian grasshoppers are known to have supernumerary or B chromosomes which are mitotically unstable in the germ line, i.e. Atractomorpha bedeli (Sannomiya and Kayano, 1969), Calliptamus palaestinensis (Nur, 1963), Camnula pellucida (Carrol, 1920; Nur, 1969), Gonista bicolor (Sannomiya, unpublished), Locusta migratoria (Itoh, 1934; Rees and Jamieson, 1954; Nur, 1969), Neopodismopsis abdominalis (Rothfels, 1950), and Patanga japonica (Sannomiya, 1962). Nur (1963) suggested that mitotically unstable B's were maintained in association with an accumulation mechanism. This suggestion has been verified in Camnula pellucida, in which a higher mean number of B's is found in meiocytes than in cells of the gastric caeca (Nur, 1969). In the case of $C$. pellucida, however, the meiocytes and the cells of the gastric caeca were studied in different individuals. Of course, the best procedure is to establish the number of B's in the meiocytes and the cells of the gastric caeca using the same individual. This procedure has been utilised in Locusta migratoria, and the results reported below indicate that in this species also the B's accumulate in the germ line.

\section{Materials AND MEthods}

Testes were vivisected from males of Locusta migratoria $\mathbf{L}$. collected on the campus of Kyushu University (Hakozaki) in the autumn of 1969 and fixed with Newcomer's fluid (Newcomer, 1953). Each male was then injected with 0.05 c.c. of 0.03 per cent. aqueous solution of demecolcine ( $K \& \mathrm{~K}$ Laboratories Inc., New York). Eighteen hours after the injection surviving males were dissected and gastric caeca were fixed with acetic alcohol (1:3). The utilisation of gastric caeca for studying mitosis was reported by Nankivell (1967) and Nur (1969). For preparations of somatic cells and primary spermatocytes, the gastric caeca and the testes were stained in toto with hydrochloric acid-carmine and squashed in 45 per cent. acetic acid (Snow, 1963). A total of 40 males were available for studying mitosis in the cells of the gastric caeca. Six males (Nos. 8, 9, 13, 22, 27 and 28) each with $1 \mathrm{~B}$ and four males (Nos. 2, 4, 6 and 24) each with 2 B's in the cells of the gastric caeca were used for the analysis of primary spermatocytes and cells at MI were observed. Fifty follicles were studied per male, except for one male (No. 2) in which only 45 follicles were available.

* Contribution from Department of Biology, Faculty of Science, Kyushu University, No. 181 . 


\section{Results AND DISCUSSION}

The $\mathrm{B}$ chromosomes of $L$. migratoria are the same in size as the smallest A chromosomes and they are not identifiable at mitotic (plate I, fig. 1) or at meiotic metaphase (plate I, fig. 2), except for the univalent(s). At MI of the primary spermatocyte two or more B's tend to be paired. Thus in the cells with 2 B's a B-bivalent is formed in almost all the cells and in the cells with 4 B's two B-bivalents (plate I, fig. 2) are frequently formed. The data of pairing of B's as shown in table 1 were scored in primary spermatocytes from 16 follicles with 2 B's, 12 follicles with 3 B's, six follicles with 4 B's, and one follicle with 5 B's from male No. 6 (for the numbers of cells studied see table 2).

TABLE 1

Pairings of $B$ 's at $M I$ in primary spermatocytes

\begin{tabular}{|c|c|c|c|c|c|}
\hline & Configuration & $\begin{array}{c}\text { Frequency } \\
(\%)\end{array}$ & & Configuration & $\begin{array}{c}\text { Frequency } \\
(\%)\end{array}$ \\
\hline $2 B$ & $\begin{cases}1 & \mathrm{II} \\
2 & \mathrm{I}\end{cases}$ & $\begin{array}{r}99 \cdot 3 \\
0.7\end{array}$ & $4 \mathrm{~B}$ & $\begin{cases}1 & \mathrm{IV} \\
1 & \mathrm{III}+1 \mathrm{I} \\
2 & \mathrm{II} \\
\mathrm{I} & \mathrm{II}+2 \mathrm{I} \\
4 & \mathrm{I}\end{cases}$ & $\begin{array}{r}2 \cdot 0 \\
8 \cdot 7 \\
68 \cdot 9 \\
19 \cdot 4 \\
1 \cdot 0\end{array}$ \\
\hline $3 B$ & $\begin{cases}1 & \text { III } \\
1 & \text { II + I I } \\
3 & \text { I }\end{cases}$ & $\begin{array}{r}4 \cdot 3 \\
87 \cdot 8 \\
7 \cdot 9\end{array}$ & & $\begin{cases}2 & \mathrm{II}+1 \mathrm{I} \\
1 \mathrm{II}+3 & \mathrm{I}\end{cases}$ & $\begin{array}{l}81 \cdot 8 \\
18 \cdot 2\end{array}$ \\
\hline
\end{tabular}

Since intra-individual variation in the number of B's in the cells of the gastric caeca was not found or, if any, found very rarely, the 40 males were classified into the following zygotic types (the number of males in parentheses): $0 \mathrm{~B}(14), 1 \mathrm{~B}(15), 2 \mathrm{~B}(8), 3 \mathrm{~B}(2)$ and $4 \mathrm{~B}(1)$. The frequency of males with B's, 65 per cent., approximates very closely to 66 per cent. that observed by Nur (1969) studying 39 males sampled in 1965 at the same locality.

As far as the 10 males in which both mitosis and meiosis were studied, no intra-individual variation in the number of B's was found in the cells of the gastric caeca: In six males with $1 \mathrm{~B}$ in the cells of the gastric caeca the numbers of cells observed per male were $41,36,25,12,8$ and 18 respectively, and in four males with 2 B's in the cells of the gastric caeca (plate I, fig. 1) the numbers of cells observed per male were 39,3,21 and 50 respectively. On the other hand, inter- as well as intra-follicular variations in the number of B's were found in primary spermatocytes. As an example, the data from male No. 6 are shown in table 2, in which the frequencies of the different types $(0 \mathrm{~B}, 1 \mathrm{~B}, 2 \mathrm{~B}$, etc.) of primary spermatocytes are different from follicle to follicle.

Table 3 shows the frequencies of the different types of primary spermatocytes and the mean numbers of B's per primary spermatocyte for the 10 males with B's. Mean numbers of B's per primary spermatocytes are remarkably different among the males with $1 \mathrm{~B}$ as well as among the males with 2 B's in the cells of the gastric caeca (table 3). Because in the cells of the gastric caeca no variation in the number of B's is found within the male the number of B's in the cells of the gastric caeca is taken as the standard, 
i.e. the original number of B's in the male. The mean numbers of B's per primary spermatocyte are higher than 1.00 in the males with $1 \mathrm{~B}$ in the cells

TABLE 2

The number of B's in the primary spermatocytes of male No. 6 which had $2 B$ 's in the cells of the gastric caeca

\begin{tabular}{|c|c|c|c|c|c|c|c|c|}
\hline \multirow[b]{2}{*}{$\begin{array}{l}\text { No. of } \\
\text { follicles obs. }\end{array}$} & \multirow{2}{*}{$\begin{array}{l}\text { Mean no. of } \\
\text { B's per cell }\end{array}$} & \multicolumn{6}{|c|}{ Frequency $(\%)$ of cells with } & \multirow{2}{*}{$\begin{array}{l}\text { No. of cells } \\
\text { obs. }\end{array}$} \\
\hline & & $\mathrm{OB}$ & $1 \mathrm{~B}$ & 2B & $3 B$ & $4 \mathrm{~B}$ & $5 \mathrm{~B}$ & \\
\hline 4 & $1 \cdot 00$ & - & 100 & - & - & - & - & 90 \\
\hline 16 & $2 \cdot 00$ & - & - & 100 & - & - & - & 275 \\
\hline 1 & $2 \cdot 06$ & - & - & 94 & 6 & - & - & 17 \\
\hline 1 & $2 \cdot 15$ & - & - & 85 & 15 & - & - & 34 \\
\hline 1 & $2 \cdot 73$ & - & - & 27 & 73 & - & - & 15 \\
\hline 1 & $2 \cdot 86$ & - & - & 14 & 86 & - & - & 28 \\
\hline 1 & $2 \cdot 92$ & - & - & 8 & 92 & - & - & 13 \\
\hline 1 & 2.97 & - & - & 3 & 97 & - & - & 29 \\
\hline 12 & $3 \cdot 00$ & - & - & - & 100 & - & - & 189 \\
\hline 1 & $3 \cdot 02$ & - & - & - & 98 & 2 & - & 48 \\
\hline 1 & $3 \cdot 38$ & - & - & - & 62 & 38 & - & 8 \\
\hline 1 & 3.94 & - & - & - & 6 & 94 & - & 17 \\
\hline 6 & $4 \cdot 00$ & - & - & - & - & 100 & - & 103 \\
\hline 1 & $4 \cdot 02$ & - & - & - & - & 98 & 2 & 41 \\
\hline 1 & $4 \cdot 17$ & - & - & - & - & 83 & 17 & 6 \\
\hline 1 & $5 \cdot 00$ & - & - & - & - & - & 100 & 11 \\
\hline 50 & $2 \cdot 70$ & 一 & $8 \cdot 0$ & $36 \cdot 6$ & 34.7 & $18 \cdot 3$ & $2 \cdot 4$ & Total 924 \\
\hline
\end{tabular}

of the gastric caeca and higher than 2.00 in the males with $2 \mathrm{~B}$ 's in the cells of the gastric caeca (table 3 ). These indicate evidently that B's accumulate in the germ line. The rates of accumulation of the B's, however, are different

TABLE 3

The number of $B$ 's in the cells of the gastric caeca and in the primary spermatocytes of 10 males of $\mathrm{L}$. migratoria

\begin{tabular}{|c|c|c|c|c|c|c|c|c|c|c|}
\hline \multirow{3}{*}{\multicolumn{2}{|c|}{$\begin{array}{cc}\text { Cells } \\
\text { of } \\
\text { gastric } \\
\text { caeca }\end{array}$}} & \multicolumn{9}{|c|}{ Primary spermatocytes } \\
\hline & & \multicolumn{7}{|c|}{ Frequency $(\%)$ of cells with } & \multirow{2}{*}{$\begin{array}{c}\text { Mean no. } \\
\text { of B's } \\
\text { per cell }\end{array}$} & \multirow{2}{*}{$\begin{array}{l}\text { No. of } \\
\text { cells } \\
\text { obs. }\end{array}$} \\
\hline & & OB & 1B & 2B & 3B & 4B & 5B & $6 \mathrm{~B}$ & & \\
\hline No. 22 & & 1.5 & $96 \cdot 2$ & $2 \cdot 3$ & - & - & - & - & $1 \cdot 01$ & 1346 \\
\hline No. 13 & & 1.8 & $78 \cdot 3$ & $19 \cdot 8$ & $0 \cdot 1$ & - & - & - & $1 \cdot 18$ & 1384 \\
\hline No. 28 & & $6 \cdot 0$ & $72 \cdot 0$ & $20 \cdot 0$ & $2 \cdot 0$ & -- & - & - & $1 \cdot 18$ & 1413 \\
\hline No. 9 & $1 \mathrm{~B}$ & $2 \cdot 4$ & $79 \cdot 2$ & $12 \cdot 2$ & $6 \cdot 2$ & - & - & - & $1 \cdot 22$ & 1855 \\
\hline No. 8 & & $5 \cdot 1$ & $68 \cdot 6$ & $24 \cdot 3$ & - & $2 \cdot 0$ & - & - & $1 \cdot 25$ & 1561 \\
\hline No. 27 & & $0 \cdot 6$ & $61 \cdot 1$ & $30 \cdot 3$ & $4 \cdot 0$ & $4 \cdot 0$ & - & - & $1 \cdot 50$ & 1459 \\
\hline No. 2 ) & & - & $8 \cdot 0$ & $78 \cdot 5$ & $9 \cdot 3$ & $4 \cdot 1$ & $0 \cdot 1$ & - & $2 \cdot 10$ & 1385 \\
\hline No. 4 & & - & $2 \cdot 1$ & $86 \cdot 5$ & $8 \cdot 3$ & $3 \cdot 1$ & - & - & $2 \cdot 12$ & 1772 \\
\hline No. 6 & 2B & - & $8 \cdot 0$ & $36 \cdot 6$ & $34 \cdot 7$ & $18 \cdot 3$ & $2 \cdot 4$ & 一 & $2 \cdot 70$ & 924 \\
\hline No. 24 & & - & $12 \cdot 4$ & $27 \cdot 1$ & $29 \cdot 9$ & $23 \cdot 5$ & $6 \cdot 8$ & $0 \cdot 3$ & $2 \cdot 86$ & 1327 \\
\hline Means & & 1.74 & $48 \cdot 59$ & $33 \cdot 76$ & $9 \cdot 45$ & $5 \cdot 50$ & 0.93 & $0 \cdot 03$ & $1 \cdot 712$ & - \\
\hline
\end{tabular}

from male to male, varying from 1 to 50 per cent. in the males with one B in the cells of the gastric caeca and from 5 to 43 per cent. in the males with two B's in the cells of the gastric caeca, the average being 22.5 per cent. 
Nur (1969) observed intra-individual variations in the number of B's in primary spermatocytes of Locusta migratoria from Japan. He assumed that the males with a mean number of B's lower than 2.00 developed from zygotes with $1 \mathrm{~B}$, and estimated that the rate of accumulation of B's in males from Misima was 27 per cent. and in males from Hakozaki (sampled in 1965) was 32 per cent. He remarked that the rate of accumulation of B's in L. migratoria was lower than that calculated from Camnula pellucida (36-37 per cent.) and Calliptamus palaestinensis (44 per cent.). It is of interest to estimate more accurately the rate of accumulation of the B's in this population and further work on L. migratoria is planned.

As mentioned earlier, intra-individual variations in the number of B's in primary spermatocytes of $L$. migratoria were inter- as well as intra-follicular. The intra-follicular variations, however, were usually minor, without a definite tendency toward increase or decrease in the number of B's (cf. table 2). This indicates that the pattern of distribution of the frequencies of B's in primary spermatocytes is determined primarily by non-disjunction of B's at mitoses associating with the differentiation of the follicle, and the nondisjunction is preferential in that the cells with increased numbers of B's are more frequently contributed to the germ line than those with decreased numbers of B's. Nur (1963) suggested originally that variation in the number of B's due to non-disjunction would be maintained in association with accumulation mechanisms, stating that " a tendency toward mitotic non-disjunction would probably be selected against because it makes the adjustment of the individual and the population to an optimal number of supernumeraries more difficult. Thus a supernumerary with a tendency toward mitotic non-disjunction will probably be eliminated unless the nondisjunction increases the likelihood of transmission to future generations."

\section{Summary}

1. In Locusta migratoria, the study of 10 males with B chromosomes revealed no variation in the number of B's within individuals in the cells of the gastric caeca. On the other hand the number of B's present in the primary spermatocytes varied within the same individual.

2. In six males with $1 \mathrm{~B}$ in the cells of the gastric caeca the mean numbers of B's per primary spermatocyte were $1 \cdot 01,1 \cdot 18,1 \cdot 18,1 \cdot 22,1 \cdot 25$ and $1 \cdot 50$ respectively. In four males with $2 \mathrm{~B}$ 's in the cells of the gastric caeca the mean numbers of B's per primary spermatocyte were $2 \cdot 10,2 \cdot 12,2 \cdot 70$ and $2 \cdot 86$ respectively. These facts prove that in L. migratoria B's accumulate in the germ line.

Acknowledgments.-The writer is grateful to Dr U. Nur, Department of Biology, University of Rochester, for his kind reading of the draft and making valuable suggestions to improve the manuscript.

\section{REFERENGES}

CARROL, m. 1920. An extra dyad and an extra tetrad in the spermatogenesis of Camnula pellucida (Orthoptera): Numerical variation in the chromosome complex within the individual. 7. Morph., 34, 375-455.

гтон, н. 1934. Chromosomal variation in the spermatogenesis of a grasshopper, Locusta danica L. Japan. 7. Genetics, 10, 115-134. 

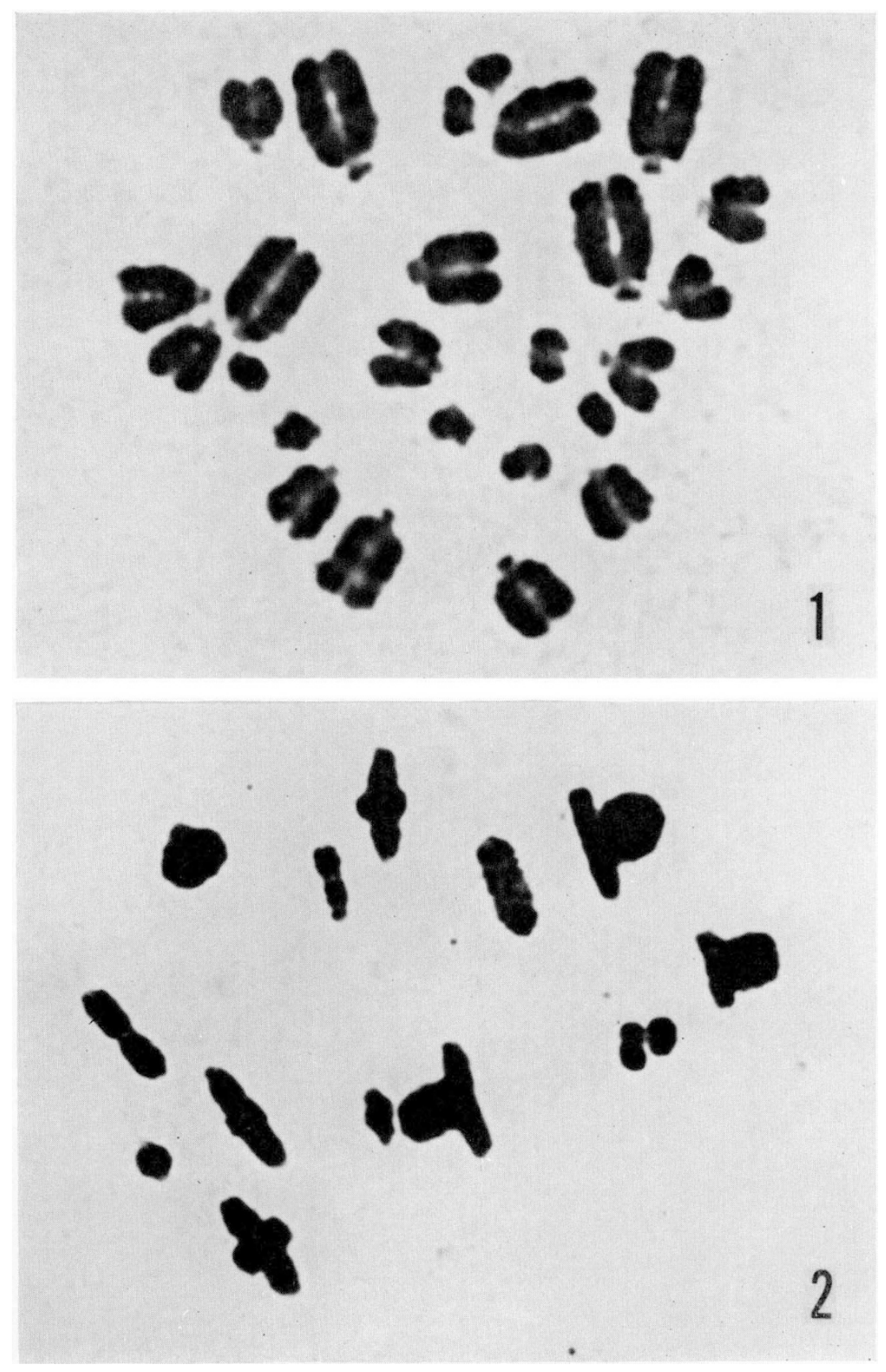

Chromosomes of male Locusta migratoria.

Fig. 1.-Metaphase of a cell of a gastric caecum $\left(2 n \sigma^{*}=22+\mathrm{XO}+2 \mathrm{~B}\right) \cdot \times 3000$.

FIg. 2.-MI of a primary spermatocyte with 4 B's, showing $13 \mathrm{II}+\mathrm{X}$ in which B's form two of five smallest bivalents (from a male with 2 B's in the cells of the gastric caeca). $\times 2000$. 
NANKIVELL, R. N. 1967. A terminal association of two pericentric inversions in first metaphase cells of the Australian grasshopper Austroicetes interioris (Acrididae). Chromosoma, 22, 42-68.

NEWCOMER, E. H. 1953. A new cytological and histological fixing fluid. Science, 118, 161. NUR, U. 1963. A mitotically unstable supernumerary chromosomes with an accumulation mechanism in a grasshopper. Chromosoma, 14, 407-422.

NUR, U. 1969. Mitotic instability leading to an accumulation of B-chromosomes in grasshoppers. Chromosoma, 27, 1-19.

REES, H. AND JAMTESON, A. 1954. A supernumerary chromosome in Locusta. Nature, 173, $43-44$.

ROTHFELS, K. H. 1950. Chromosome complement, polyploidy, and supernumeraries in Neopodismopsis abdominalis (Acrididae). 7. Morph., 87, 287-316.

sNow, R. 1963. Hydrochloric acid-carmine as a stain for chromosomes in squash preparations. Stain Technol., 38, 9-13.

SANNOMTY, M. 1962. Intra-individual variation in number of A- and B-chromosomes in Patanga japonica. CIS, 3, 30-32.

SANNOMTYA, M. AND KAYANO, H. 1969. Local variation and year-to-year change in frequencies of B-chromosomes in natural populations of two grasshopper species. Japan. $\mathcal{F}$. Genetics, 44, Suppl. 1, 84-92. 